Case Report

\title{
Nasal Chondromesenchymal Hamartoma: Rare Case Report in an Elderly Patient and Brief Review of Literature
}

\author{
Kanish Mirchia (D) and Rana Naous $(\mathbb{D}$ \\ Department of Pathology, SUNY Upstate Medical University, Syracuse, NY 13210, USA \\ Correspondence should be addressed to Kanish Mirchia; mirchiak@upstate.edu
}

Received 29 May 2018; Accepted 24 September 2018; Published 14 October 2018

Academic Editor: Stefan Pambuccian

Copyright (C) 2018 Kanish Mirchia and Rana Naous. This is an open access article distributed under the Creative Commons Attribution License, which permits unrestricted use, distribution, and reproduction in any medium, provided the original work is properly cited.

\begin{abstract}
Hamartomas are considered a mixture of nonneoplastic tissue, which may be indigenous to a different location in the body. As such, they may be epithelial, mesenchymal, or mixed. In the sinonasal region, the following hamartomatous lesions are considered to lie on a spectrum and include respiratory epithelial adenomatoid hamartoma (REAH), chondro-osseous respiratory epithelial adenomatoid hamartoma (COREAH), and nasal chondromesenchymal hamartoma (NCMH). To our knowledge, less than 50 cases of sinonasal hamartomas have been reported in the English literature so far with NCMH being very rare and primarily a tumor in infancy, with only 2 cases reported in individuals older than 16 years of age. We report a highly unusual case of a NCMH in the right maxillary sinus of a 70 -year-old female.
\end{abstract}

\section{Case Report}

A 70-year-old female presented with a two-year history of slowly growing, nonpainful maxillary sinus mass. She has a history of chronic maxillary sinusitis corresponding to presentation of the mass, with the first episode reported in 2014. Computed tomography (CT) imaging revealed an erosive right maxillary sinus mass $(2.5 \times 2.1 \mathrm{~cm})$ with bony destruction.

Surgical excision of the right maxillary sinus mass revealed a fragmented, white, vaguely nodular, and whorled lesion. Histological examination revealed fragments of respiratory-type epithelium with focal cystic invagination and associated squamous metaplasia [Figure 1]. The underlying stroma consisted of a variably cellular, benign spindle cell proliferation with an associated background of hyalinization [Figure 2], calcification and ossification [Figure 3], and focal chondroid change [Figure 4] in a vague lobule-like arrangement. Focal areas of aneurysmal and cystic changes [Figure 5] were seen which would provide an explanation for the clinically noted enlargement since hamartomas by definition would be expected to have a much lower rate of growth. The intrinsic slow-growing nature is also supported by the deficit of mitotic activity even in the highly cellular/spindled regions of the lesion (less than $1 / 10 \mathrm{hpf}$ ). Areas with haphazard arrangement of nerve bundles within the collagenous stroma [Figure 6] were also noted. Immunohistochemical stains were positive for SMA [Figures 7(a) and 7(b)] in the spindle cells and negative for CK AE1/AE3, EMA, CD34, Stat6, ERG/FLI1, Mucin 4, S-100, Sox-10, and desmin [Figure 8] ; ruling out perineurioma, solitary fibrous tumor, a vascular neoplasm, Evans tumor, a benign peripheral nerve sheath tumor, or a myogenic neoplasm. The overall findings were suggestive of a hamartomatous lesion, most likely a nasal chondromesenchymal hamartoma. The absence of submucosal glandular proliferation, myxoid stroma, or mucinous metaplasia in the lining epithelium lowers the likelihood of other neoplastic hamartomatous lesions such as COREAH.

\section{Discussion}

Nasal chondromesenchymal hamartomas are most commonly seen in the nasal cavity of children less than 3 months old, with less common involvement of the paranasal sinuses [2]. As per one review [1], mean age for NCMH was 9.6 years. Review of the English PubMed literature reveals 43 cases [Table 1] of NCMH previously published, with our case being 


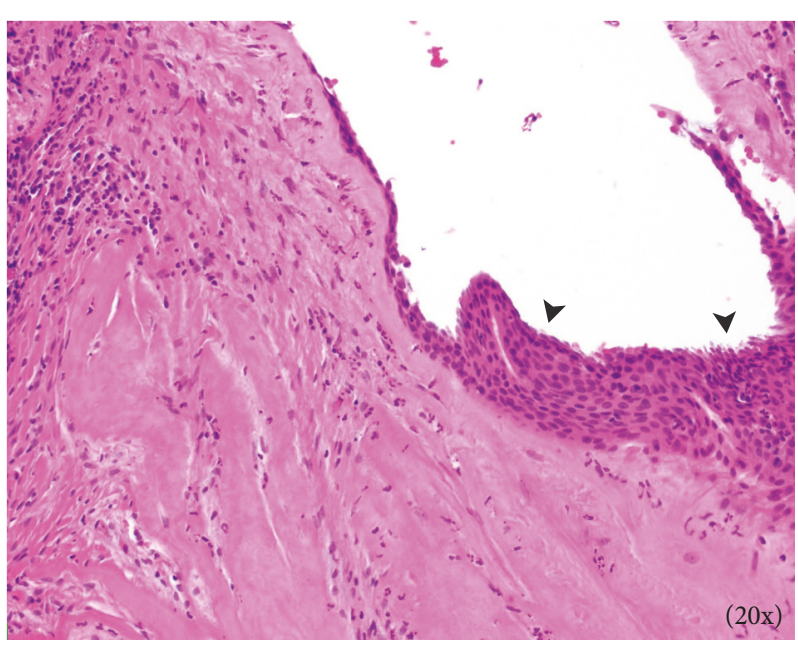

FIGURE 1: Area of respiratory lining epithelium with squamous metaplastic change (arrowheads).

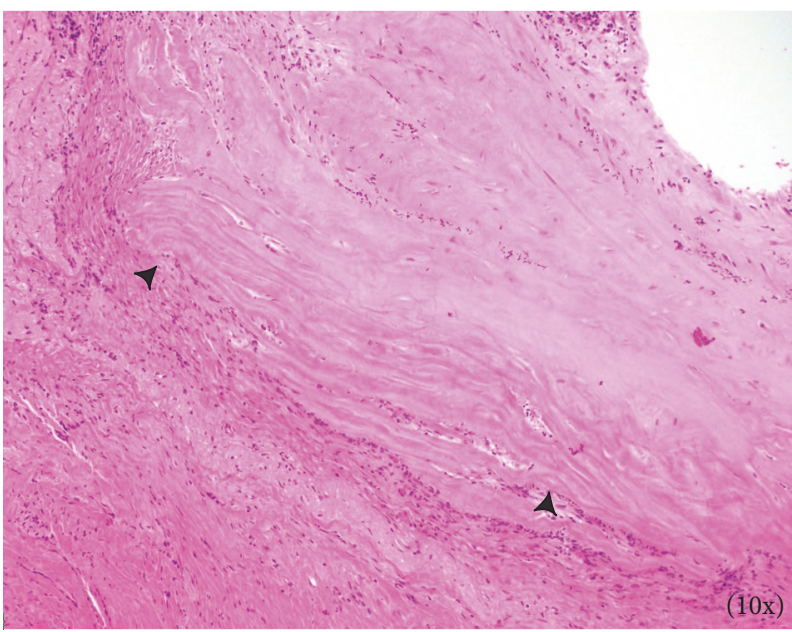

FIGURE 2: Focal areas of stroma displaying hyalinization (arrowheads).

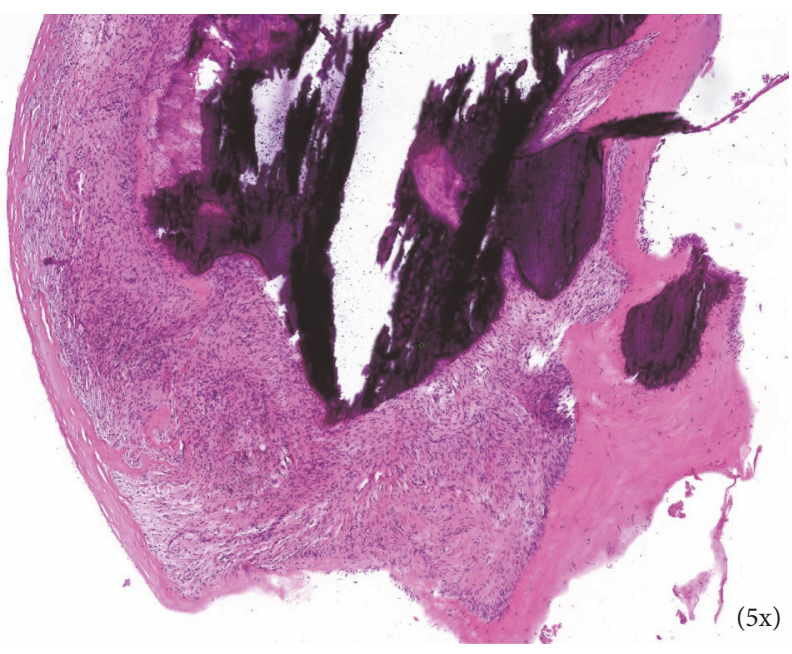

FIGURE 3: Focal areas displaying calcification and ossification surrounded by variably spindled stroma. 


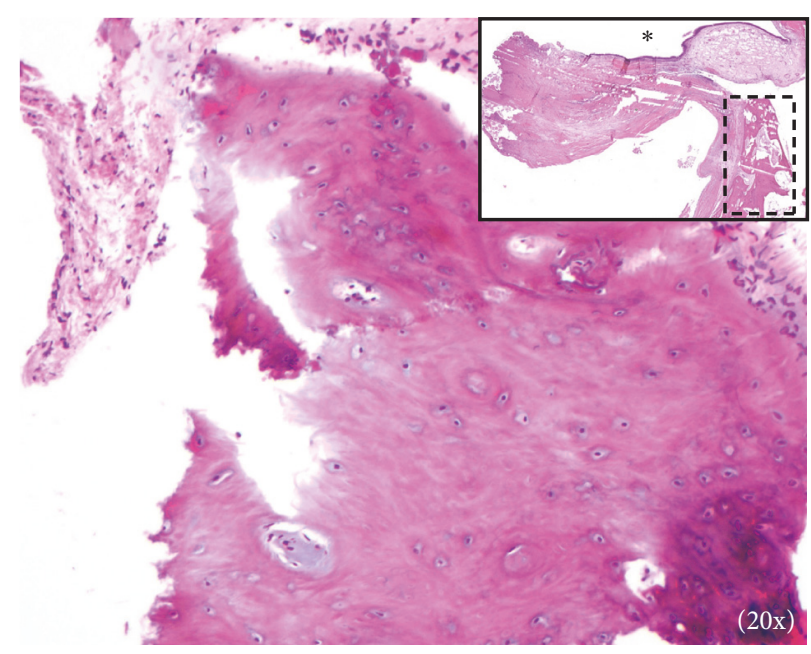

FIGURE 4: Chondroid regions which support the hamartomatous nature of the lesion. Inset shows area at low-power with spatial relation of components, including surface ciliated epithelium $(*)$ and bone (within dashed lines).

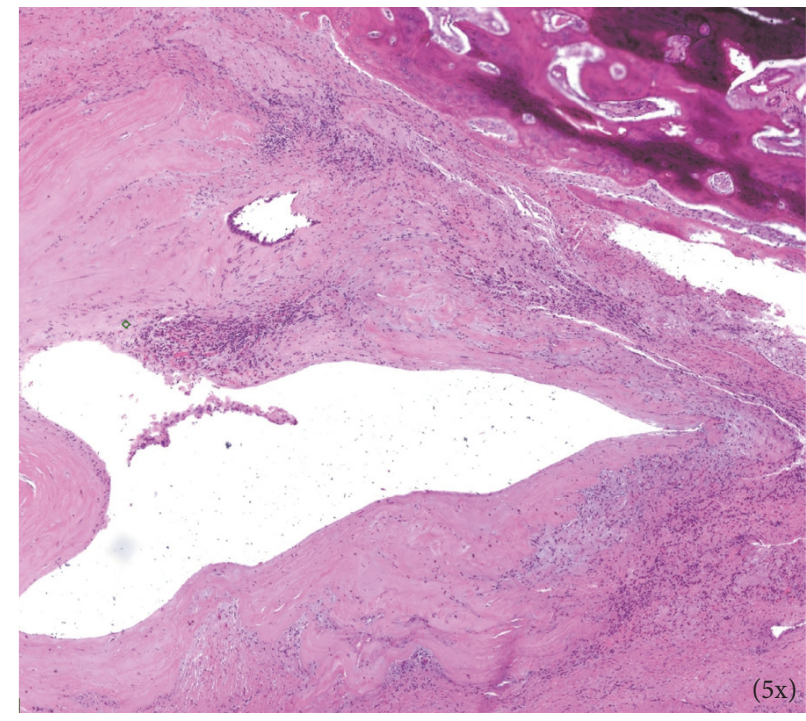

FIGURE 5: Variably dilated cystic regions within the lesion.

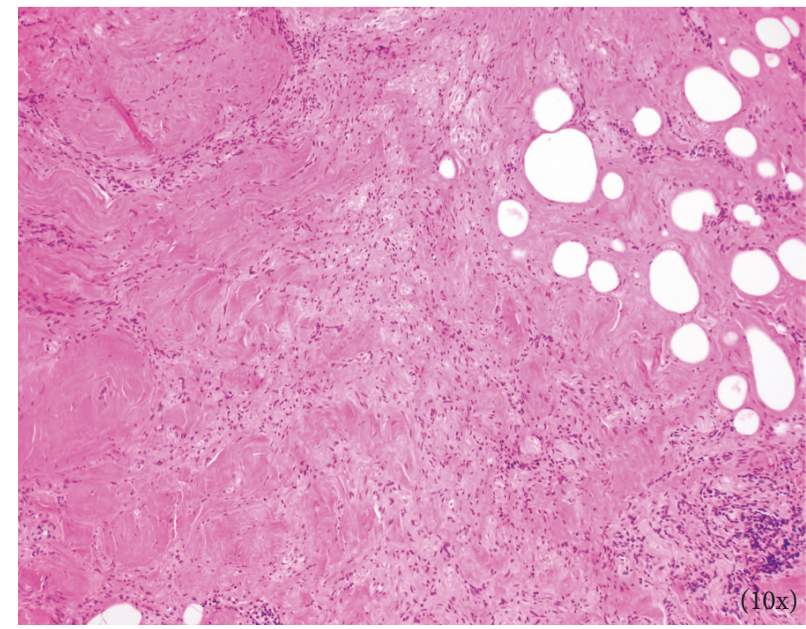

FIGURE 6: Disorganized bundles of nervous tissue interspersed within collagenous stroma. 


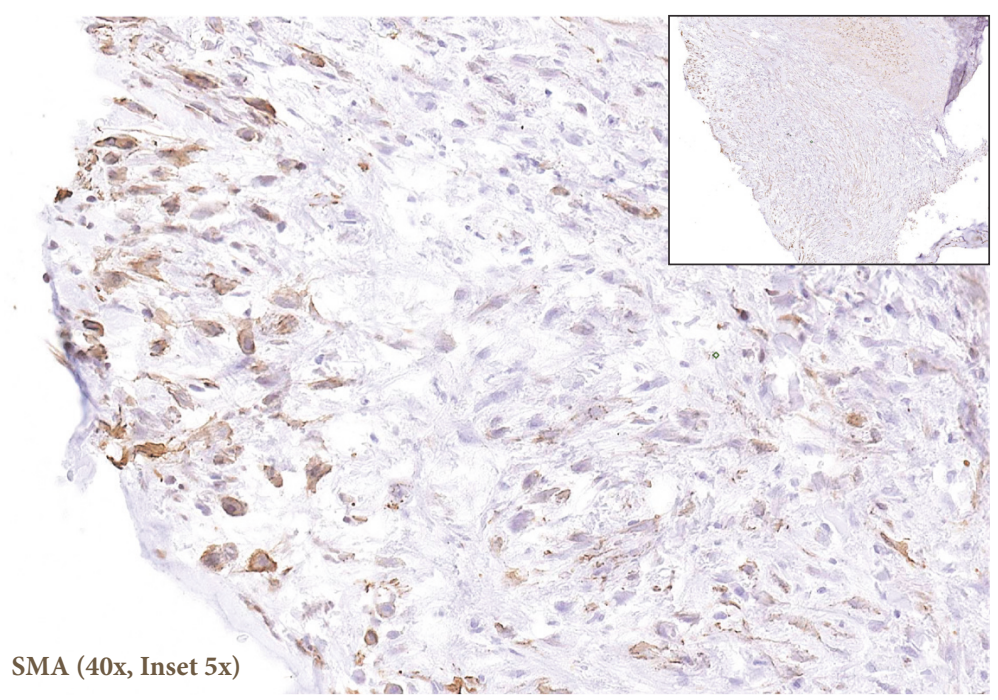

(a)

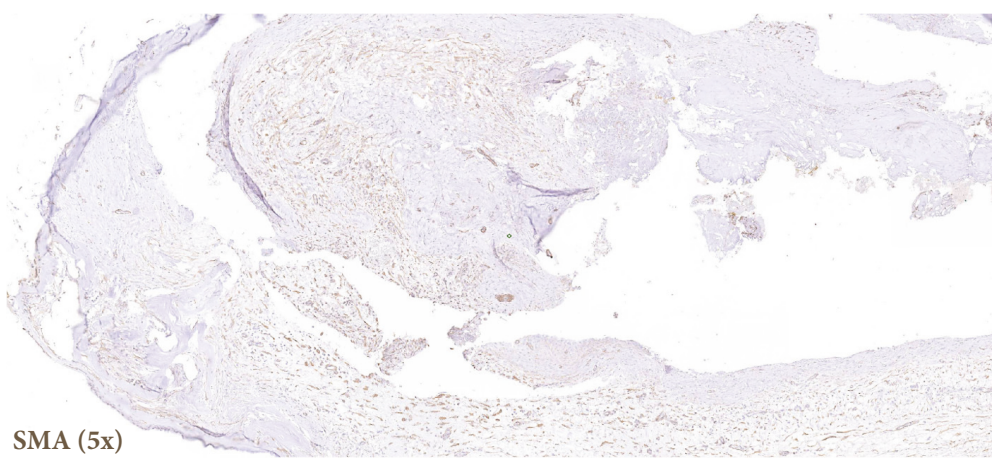

(b)

FIGURE 7: Immunohistochemistry for smooth muscle actin (SMA) showing positive staining in the spindled lesional cells.
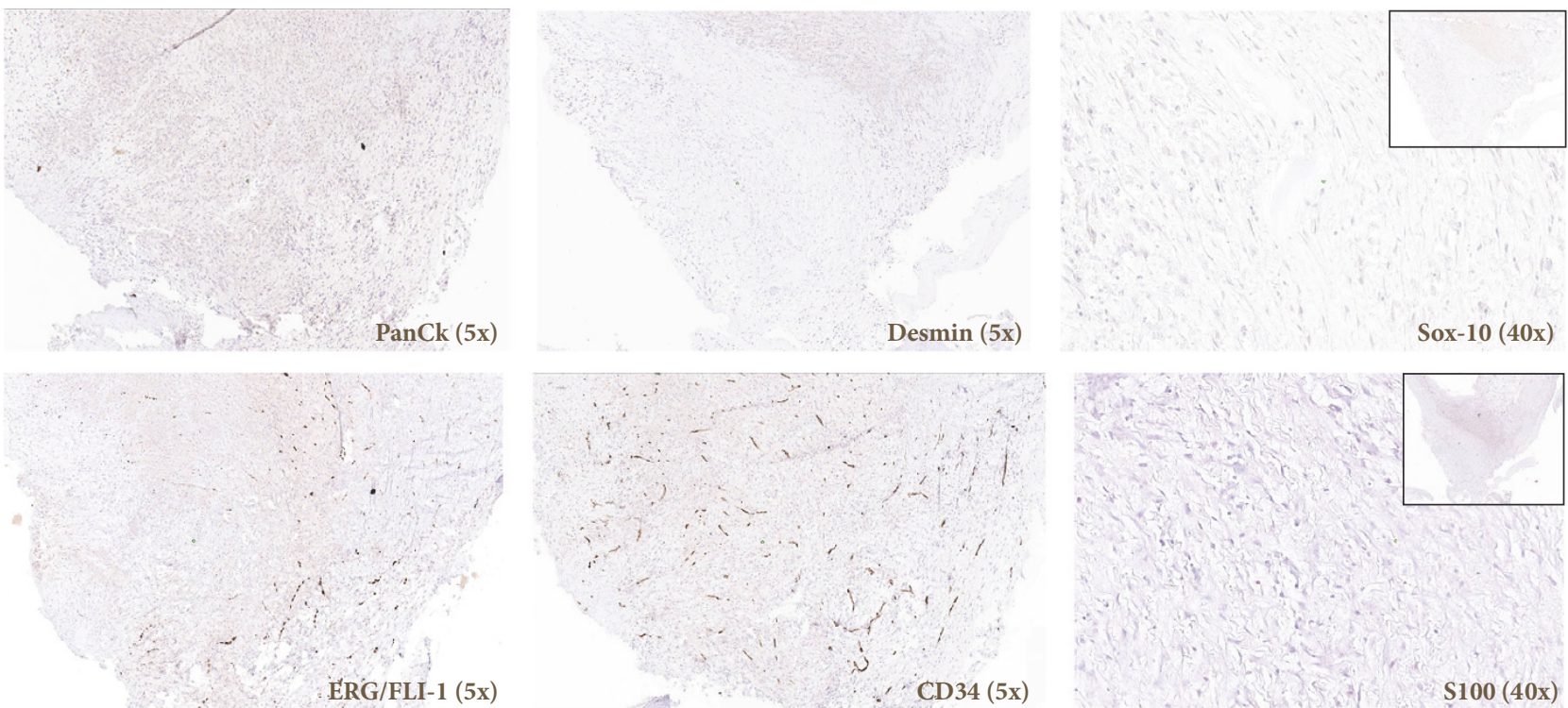

FIGURE 8: Lesional cells are negative for pan-cytokeratin (ael/ae3), desmin, Sox-10, and S100. CD34 and ERG/FLI-1 highlight vascular endothelial cells. 
TABLE 1: Brief review of cases of nasal chondromesenchymal hamartomas reported in the English literature. Some cases also reported in older review articles [1].

\begin{tabular}{|c|c|c|c|c|c|c|}
\hline Age & Sex & $\begin{array}{c}\text { Follow-up } \\
\text { (Asymptomatic) }\end{array}$ & Site & Pertinent Information & Study & Year \\
\hline 5 days & $\mathrm{M}$ & 2 years & Nasal cavity & - & [2] McDermott & 1998 \\
\hline 12 days & $\mathrm{F}$ & $<16$ months & Nasal cavity & Intracranial extension & [2] McDermott & 1998 \\
\hline 14 days & $\mathrm{M}$ & - & $\begin{array}{c}\text { Nasal cavity } \\
\text { Ethmoid Sinus }\end{array}$ & $\begin{array}{c}\text { Intracranial extension } \\
\text { Residual tumor } \\
\end{array}$ & [2] McDermott & 1998 \\
\hline 2 months & $\mathrm{M}$ & 18 months & Nasal cavity & Intracranial extension & [2] McDermott & 1998 \\
\hline 3 months & $\mathrm{F}$ & 2 years & $\begin{array}{c}\text { Nasal cavity } \\
\text { Ethmoid Sinus }\end{array}$ & $\begin{array}{c}\text { Intracranial extension } \\
\text { Residual tumor } \\
\end{array}$ & [2] McDermott & 1998 \\
\hline 3 months & $\mathrm{M}$ & 4 years & Nasal cavity & - & [2] McDermott & 1998 \\
\hline 7 years & $M$ & - & $\begin{array}{l}\text { Nasal cavity Sphenoid } \\
\text { sinus }\end{array}$ & $\boldsymbol{P P B}$, multiple recurrences & [2] McDermott & 1998 \\
\hline 4 months & $\mathrm{M}$ & 13 years & Nasal cavity & Intracranial extension & [3] Kato & 1999 \\
\hline 0 days & M & 5 years & $\begin{array}{c}\text { Nasal cavity } \\
\text { Sphenoiod sinus } \\
\text { Ethmoid sinus }\end{array}$ & Orbital compression & [4] Hsueh & 2001 \\
\hline 9 months & $\mathrm{M}$ & 9 months & Nasal cavity & - & [4] Hsueh & 2001 \\
\hline 16 years & $M$ & 8 months & Nasal cavity & 3-month history & [5] Alrawi M & 2003 \\
\hline 5 months & $\mathrm{M}$ & - & Nasal cavity & Orbital compression & [6] Kim B & 2004 \\
\hline 11 years & $M$ & - & $\begin{array}{l}\text { Nasal cavity Ethmoid } \\
\text { sinus }\end{array}$ & 8-month history & [7] Norman ES & 2004 \\
\hline 1 year & M & - & Nasal cavity & $\begin{array}{l}\text { Orbital extension } \\
\text { Residual tumor }\end{array}$ & [8] Shet T & 2004 \\
\hline 11 years & $M$ & - & $\begin{array}{l}\text { Nasal cavity Ethmoid } \\
\text { sinus }\end{array}$ & ( & [9] Ozolek JA & 2005 \\
\hline 17 years & $F$ & - & Nasal cavity & - & [9] Ozolek JA & 2005 \\
\hline 25 years & $M$ & - & $\begin{array}{l}\text { Nasal cavity Maxillary } \\
\text { sinus } \\
\end{array}$ & $\begin{array}{c}\text { Bilateral NCMH } \\
\text { Intracranial aneurysms } \\
\end{array}$ & [9] Ozolek JA & 2005 \\
\hline 69 years & $F$ & - & $\begin{array}{l}\text { Nasal cavity Ethmoid } \\
\text { sinus }\end{array}$ & ( & [9] Ozolek JA & 2005 \\
\hline 11 years & $M$ & 2 months & Nasal cavity & - & [10] Low SE & 2006 \\
\hline 15 years & $F$ & 6 months & Nasal cavity & $\begin{array}{c}\text { Bilateral NCMH } \\
\boldsymbol{P P \boldsymbol { B }} \\
\end{array}$ & [11] Johnson C & 2007 \\
\hline 7 months & $\mathrm{M}$ & 18 months & Nasal cavity & Orbital compression & [12] Silkiss RZ & 2007 \\
\hline 12 months & $\mathrm{M}$ & - & Nasal cavity & Orbital compression & [13] Finitsis S & 2009 \\
\hline 19 months & M & 10 months & Nasal cavity & $\begin{array}{c}\text { Intracranial, orbital } \\
\text { extension }\end{array}$ & [14] Kim JE & 2009 \\
\hline \multicolumn{5}{|c|}{2 cases previously reported, both with $P P B$, multiple recurrences } & [15] Priest JR & 2010 \\
\hline 10 years & $F$ & 21 months & Nasal cavity & $\begin{array}{c}\text { Bilateral } N C M H \\
P P B \\
\end{array}$ & [15] Priest JR & 2010 \\
\hline 11 years & $M$ & 4 months & Nasal cavity & $P P B$ & [15] Priest JR & 2010 \\
\hline 11 years & $M$ & - & - & $P P B$ & [16] Behery RE & 2012 \\
\hline 8 years & $M$ & 6 months & $\begin{array}{c}\text { Sphenoid sinus Ethmoid } \\
\text { sinus }\end{array}$ & 4-month history & [17] Uzomefuna & 2012 \\
\hline 14 years & $M$ & 4 years & $\begin{array}{l}\text { Nasal cavity Maxillary } \\
\text { sinus }\end{array}$ & - & [18] Cho YC & 2013 \\
\hline 23 years & $M$ & 3 months & $\begin{array}{l}\text { Nasal cavity Ethmoid } \\
\text { Sinus }\end{array}$ & Orbital extension & [19] $\mathrm{LiGY}$ & 2013 \\
\hline 40 years & $F$ & - & $\begin{array}{c}\text { Nasal cavity Ethmoid } \\
\text { Sinus } \\
\text { Maxillary sinus }\end{array}$ & $\begin{array}{c}\text { Malignant transformation } \\
\text { Recurrence }\end{array}$ & {$[20] \mathrm{LiY}$} & 2013 \\
\hline 9 months & $\mathrm{F}$ & - & $\begin{array}{c}\text { Nasal cavity } \\
\text { Maxillary sinus }\end{array}$ & Orbital compression & [21] Moon S & 2014 \\
\hline
\end{tabular}


TABle 1: Continued.

\begin{tabular}{|c|c|c|c|c|c|c|}
\hline Age & Sex & $\begin{array}{c}\text { Follow-up } \\
\text { (Asymptomatic) }\end{array}$ & Site & Pertinent Information & Study & Year \\
\hline 14 years & $M$ & - & Nasal cavity & $\begin{array}{c}\text { Bilateral } N C M H \\
\boldsymbol{P P B} \\
\end{array}$ & [22] Obidan AA & 2014 \\
\hline 6 weeks & $\mathrm{F}$ & 10 months & Nasal cavity & - & [23] Wang T & 2014 \\
\hline 5 years & $M$ & 3 years & $\begin{array}{l}\text { Nasal cavity } \\
\text { Ethmoid sinus }\end{array}$ & 4-year history & [23] Wang T & 2014 \\
\hline 10 months & $\mathrm{M}$ & 18 months & Nasal cavity & 6-month history & [24] Lee CH & 2015 \\
\hline 49 years & $M$ & $\begin{array}{c}2 \text { years } \\
4 \text { years (phone) }\end{array}$ & Nasal cavity & 5-year history & [1] Mason AK & 2015 \\
\hline \multicolumn{5}{|c|}{ Systematic review } & [1] Mason AK & 2015 \\
\hline 5 years & $M$ & - & Nasal cavity & $\begin{array}{c}\text { Previous } \\
\text { rhabdomyosarcoma in } \\
\text { remission }\end{array}$ & [25] Avci H & 2016 \\
\hline 13 years & $F$ & 12 months & Nasal cavity & 6-month history & [26] Unal A & 2016 \\
\hline 3 years & M & 3 years & Nasal cavity & - & [27] Nakaya M & 2017 \\
\hline
\end{tabular}

the oldest patient reported, and presenting with a tumor in an unusual location.

Our case would lend support to extending the age range for $\mathrm{NCMH}$ and considering it in the differential diagnosis of all sinonasal region tumors, irrespective of age, and location in the head and neck region. Despite primarily being a benign lesion, these tumors can present with areas of necrosis and local destruction, including bony invasion. The tumors can be aggressive appearing on imaging, extending into bony structures, including the cranium and/or the orbital cavity, which should not lead away from the diagnosis of this benign lesion. Detailed CT or preferably MRI prior to surgical excision should be performed.

$\mathrm{NCMH}$ has been associated with development of pleuropulmonary blastoma (PPB) during infancy. A recent [28] report highlighted the association of $\mathrm{NCMH}$ and $\mathrm{PPB}$ with DICER1 mutation and various associated entities such as lung cysts, cystic nephroma, renal sarcoma, Wilms tumor, thyroid hyperplasia, and CNS tumors. NCMH in isolation however is a benign lesion with follow-up in patients up to 16 years after excision, except for one reported case with malignant transformation in the literature [20]. Etiologically, it would make sense that cases in adults, such as ours, represent a tissue response to insult, such as chronic sinusitis rather than an inborn germline error (such as a DICER1 mutation).

Whether the presentation of a $\mathrm{NCMH}$ at a later age predisposes to malignant transformation due to the longstanding nature of the lesion is up for debate. It could represent a somatic DICER1 mutation rather than a germline mutation, causing the hamartoma to form later in age. Longer follow-up results from the adult cases and routine genetic testing in all NCMH will help provide an answer to these questions.

\section{Conclusion}

We report an unusual case of $\mathrm{NCMH}$ eroding the right maxillary sinus of a 70-year-old female. Although, $\mathrm{NCMH}$ is a rare entity with predilection for pediatric age groups, it is important to consider NCMH in the differential diagnosis of nasal/sinonasal masses in adult patients in order to avoid diagnostic errors.

\section{Conflicts of Interest}

The authors declare that there are no conflicts of interest regarding the publication of this paper.

\section{References}

[1] K. A. Mason, A. Navaratnam, E. Theodorakopoulou, and P. G. Chokkalingam, "Nasal Chondromesenchymal Hamartoma $(\mathrm{NCMH})$ : A systematic review of the literature with a new case report," Journal of Otolaryngology - Head and Neck Surgery, vol. 44, no. July, 2015.

[2] M. B. McDermott, T. B. Ponder, and L. P. Dehner, "Nasal chondromesenchymal hamartoma: An upper respiratory tract analogue of the chest wall mesenchymal hamartoma," The American Journal of Surgical Pathology, vol. 22, no. 4, pp. 425433, 1998.

[3] K. Kato, R. Ijiri, Y. Tanaka, M. Hara, and K. Sekido, "Nasal chondromesenchymal hamartoma of infancy: The first Japanese case report," Pathology International, vol. 49, no. 8, pp. 731-736, 1999.

[4] C. Hsueh, "Nasal chondromesenchymal hamartoma in children: report of 2 cases with review of the literature," Archives of Pathology \& Laboratory Medicine, vol. 125, no. 3, p. 400, 2001.

[5] M. Alrawi, M. McDermott, D. Orr, and J. Russell, "Nasal chondromesynchymal hamartoma presenting in an adolescent," International Journal of Pediatric Otorhinolaryngology, vol. 67, no. 6, pp. 669-672, 2003. 
[6] B. Kim, S.-H. Park, H. S. Min, J. S. Rhee, and K. C. Wang, "Nasal chondromesenchymal hamartoma of infancy clinically mimicking meningoencephalocele," Pediatric Neurosurgery, vol. 40, no. 3, pp. 136-140, 2004.

[7] E. S. Norman, S. Bergman, and J. K. Trupiano, "Nasal chondromesenchymal hamartoma: Report of a case and review of the literature," Pediatric and Developmental Pathology, vol. 7, no. 5, pp. 517-520, 2004.

[8] T. Shet, A. Borges, C. Nair, S. Desai, and R. Mistry, "Two unusual lesions in the nasal cavity of infants - A nasal chondromesenchymal hamartoma and an aneurysmal bone cyst like lesion - More closely related than we think?" International Journal of Pediatric Otorhinolaryngology, vol. 68, no. 3, pp. 359-364, 2004.

[9] J. A. Ozolek, "Nasal chondromesenchymal hamartoma in older children and adults: series and immunohistochemical analysis," Archives of Pathology \& Laboratory Medicine, vol. 129, no. 11, pp. 1444-50, 2005.

[10] S. E. Low, R. K. Sethi, E. Davies, and J. S. Stafford, "Nasal chondromesenchymal hamartoma in an adolescent," Histopathology, vol. 49, no. 3, pp. 321-323, 2006.

[11] C. Johnson, U. Nagaraj, J. Esguerra, D. Wasdahl, and D. Wurzbach, "Nasal chondromesenchymal hamartoma: Radiographic and histopathologic analysis of a rare pediatric tumor," Pediatric Radiology, vol. 37, no. 1, pp. 101-104, 2007.

[12] R. Z. Silkiss, S. S. Mudvari, and D. Shetlar, "Ophthalmologic presentation of nasal chondromesenchymal hamartoma in an infant," Ophthalmic Plastic \& Reconstructive Surgery, vol. 23, no. 3, pp. 243-244, 2007.

[13] S. Finitsis, C. Giavroglou, S. Potsi et al., "Nasal chondromesenchymal hamartoma in a child," CardioVascular and Interventional Radiology, vol. 32, no. 3, pp. 593-597, 2009.

[14] J.-E. Kim, H.-J. Kim, H. K. Ji, Y.-H. Ko, and S.-K. Chung, "Nasal chondromesenchymal hamartoma: CT and MR imaging findings," Korean Journal of Radiology, vol. 10, no. 4, pp. 416-419, 2009.

[15] J. R. Priest, G. M. Williams, W. A. Mize, L. P. Dehner, and M. B. McDermott, "Nasal chondromesenchymal hamartoma in children with pleuropulmonary blastoma-A report from the International Pleuropulmonary Blastoma Registry registry," International Journal of Pediatric Otorhinolaryngology, vol. 74, no. 11, pp. 1240-1244, 2010.

[16] R. El Behery, J. Bedrnicek, A. Lazenby et al., "Translocation $\mathrm{t}(12 ; 17)(\mathrm{q} 24.1 ; \mathrm{q} 21)$ as the sole anomaly in a nasal chondromesenchymal hamartoma arising in a patient with pleuropulmonary blastoma," Pediatric and Developmental Pathology, vol. 15, no. 3, pp. 249-253, 2012.

[17] V. Uzomefuna, F. Glynn, J. Russell, and M. McDermott, "Nasal chondromesenchymal hamartoma with no nasal symptoms," BMJ Case Reports, 2012.

[18] Y. C. Cho, I. Y. Sung, J. H. Son, and R. Ord, "Nasal chondromesenchymal hamartoma: Report of a case presenting with intraoral signs," Journal of Oral and Maxillofacial Surgery, vol. 71, no. 1, pp. 72-76, 2013.

[19] G.-Y. Li, B. Fan, and Y.-Y. Jiao, "Endonasal endoscopy for removing nasal chondromesenchymal hamartoma extending from the lacrimal sac region," Canadian Journal of Ophthalmology, vol. 48, no. 2, pp. e22-e23, 2013.

[20] M. Sharif and Abdul Jawad, "Interacting generalized dark energy and reconstruction of scalar field models," Modern Physics Letters A, vol. 28, no. 38, Article ID 1350180, 15 pages, 2013.
[21] S. H. Moon and M. M. Kim, "Nasal chondromesenchymal hamartoma with incomitant esotropia in an infant: A case report," Canadian Journal of Ophthalmology, vol. 49, no. 1, pp. e30-e32, 2014.

[22] A. A. Obidan and M. M. Ashoor, "Nasal chondromesenchymal hamartoma in an adolescent with pleuropulmonary blastoma," Saudi Medical Journal, vol. 35, no. 8, pp. 876-878, 2014.

[23] T. Wang, W. Li, X. Wu et al., "Nasal chondromesenchymal hamartoma in young children: $\mathrm{CT}$ and MRI findings and review of the literature," World Journal of Surgical Oncology, vol. 12, no. 1, p. 257, 2014.

[24] C. H. Lee, Y. H. Park, J. Y. Kim, and J. H. Bae, "Nasal chondromesenchymal hamartoma causing sleep-disordered breathing in an infant," International Journal of Clinical and Experimental Pathology, vol. 8, no. 8, pp. 9643-9646, 2015.

[25] H. Avcı, Ş. Çomoğlu, E. Öztürk, B. Bilgiç, and Ö. E. Kıyak, "Nasal chondromesenchymal hamartoma: a rare nasal benign tumor," Kulak burun bogaz ihtisas dergisi : KBB = Journal of ear, nose, and throat, vol. 26, no. 5, pp. 300-303, 2016.

[26] A. Ünal, R. O. Kum, Y. Avc1, and D. T. Ünal, "Nasal chondromesenchymal hamartoma, a rare pediatric tumor: Case report," The Turkish Journal of Pediatrics, vol. 58, no. 2, pp. 208-211, 2016.

[27] M. Nakaya, S. Yoshihara, A. Yoshitomi, and S. Baba, "Endoscopic endonasal excision of nasal chondromesenchymal hamartoma with intracranial extension," European Annals of Otorhinolaryngology, Head and Neck Diseases, vol. 134, no. 6, pp. 423-425, 2017.

[28] D. A. Hill, J. Ivanovich, J. R. Priest et al., "DICER1 mutations in familial pleuropulmonary blastoma," Science, vol. 325, no. 5943, p. $965,2009$. 


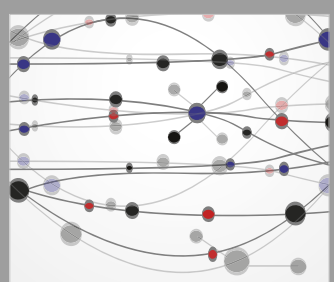

The Scientific World Journal
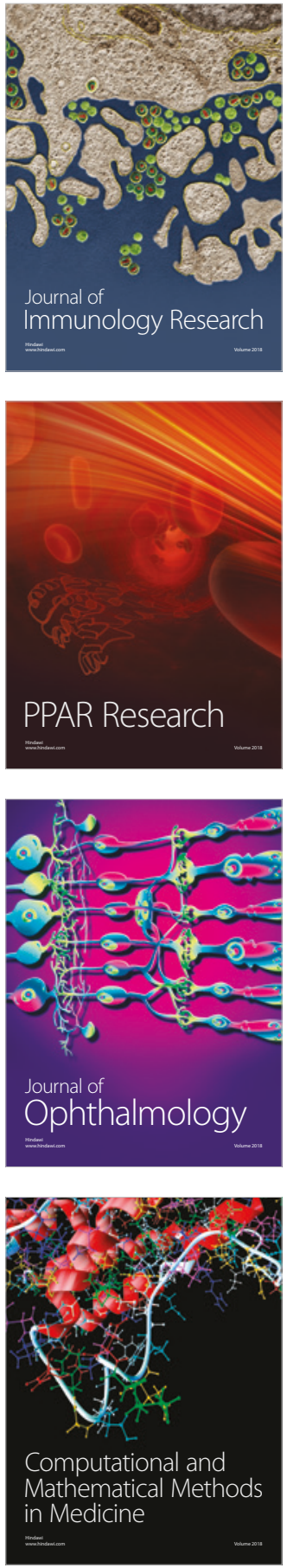

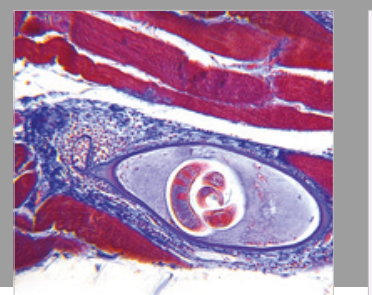

Gastroenterology Research and Practice

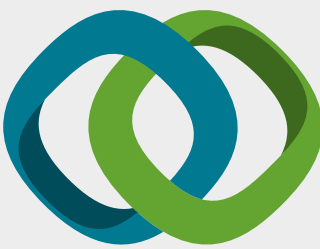

\section{Hindawi}

Submit your manuscripts at

www.hindawi.com
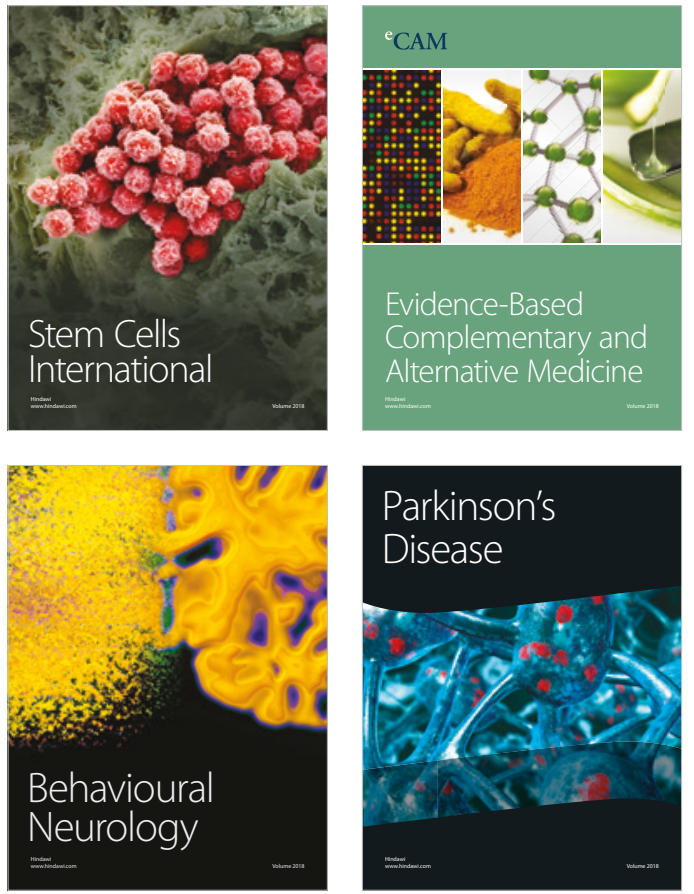

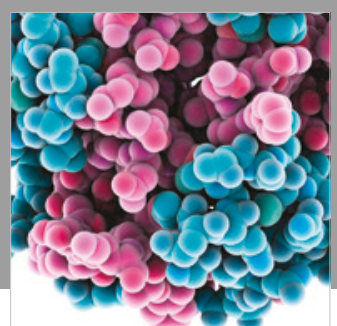

ournal of

Diabetes Research

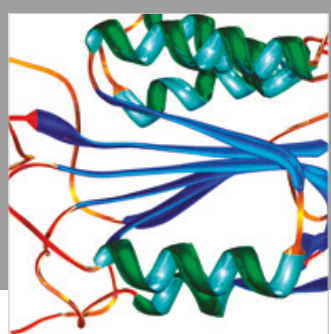

Disease Markers
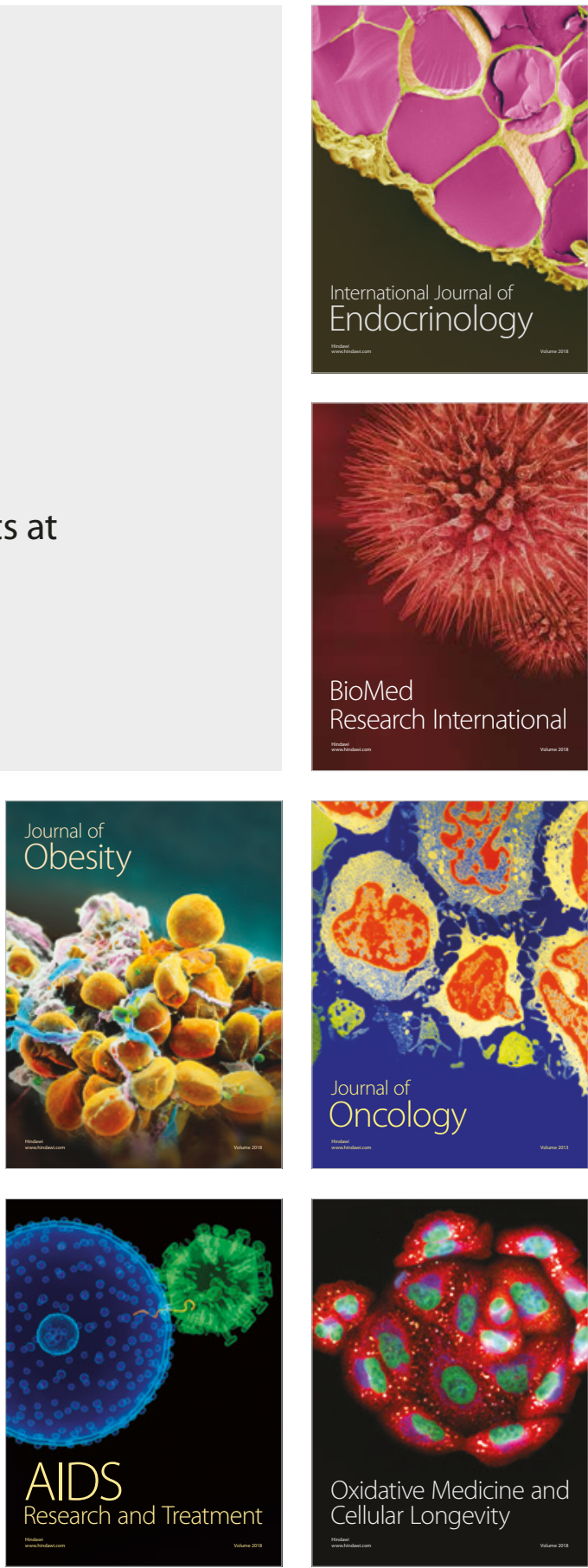